Jurnal Basicedu Volume 4 Nomor 1 Januari 2020 Halaman 36 - 43

JURNAL BASICEDU

Research \& Learning in Elementary Education

https://jbasic.org/index.php/basicedu

\title{
HUBUNGAN ANTARA DUKUNGAN SOSIAL KELUARGA DENGAN PSYCHOLOGICAL WELL-BEING PADA NARAPIDANA ANAK DI LAPAS KLAS 1 KUTOARJO
}

\author{
Yehezkiel Adi Nugroho ${ }^{1}$ \\ Universitas Kristen Satya Wacana, Jawa Timur, Indonesia \\ E-mail: rosidahcholifah@ gmail.com ${ }^{1}$,
}

\begin{abstract}
Abstrak
Penelitian ini bertujuan untuk mengetahui hubungan antara dukungan sosial dengan psychological well-being pada narapidana anak. Penelitian ini menggunakan teknik sampling jenuh dengan partisipan berjumlah 53 orang. Variabel dukungan sosial keluarga menggunakan teori Cutrona (1987) yang terdiri dari 24 item dan variabel psychological well-being menggunakan teori Ryff (1989) yang terdiri dari 42 item. Metode penelitian yang di pakai dalam pengumpulan data dengan metode skala, yaitu skala dukungan sosial keluarga dan Ryff's psychological well-being scale. Analisis data menggunakan teknik analisis korelasi product moment dan diperoleh koefisien korelasi 0,688 dengan nilai sig. $=0,000(\mathrm{p}<0,001)$. Hasil penelitian menunjukan ada hubungan positif antara dukungan sosial keluarga dengan psychological well-being pada narapidana anak di lapas kutoarjo.
\end{abstract}

\section{Kata Kunci: Dukungan Sosial Keluarga, Psychological well-being, Narapidana Anak.}

\begin{abstract}
The research aims to knowing the relationship between social support and psychological well-being in child prisoner. This research is designed by using sampling saturated technique with 53 participants. Variable of family social support using Cutrona's theory (1987) which consist of 24 items and psychological well-being variable using Ryff's theory (1989) which consists of 42 items. The research method in data collecyion using scale method. That is the scale of family social support and the Ryff's psychological well-being scale. Data analysis using the product moment correlation analysis techniques and obtained a comparison coefficient of 0,688 with a sig value. $=0,000(p<0,001)$. Based on the research result shows a positive relationship between family social support and psychological well-being on child prisoner in prison in kutoarjo.
\end{abstract}

Keywords: Family Social Support, Psychological well-being, child prisoner.

@ Jurnal Basicedu Prodi PGSD FIP UPTT 2020

Corresponding author:

Address :-

Email : :

ISSN 2580-3735 (Media Cetak)

Phone :- 
37 Hubungan antara dukungan sosial keluarga dengan psychological well-being paa narapidana anak di Lapas Klas 1 Kutoarjo - Yehezkiel Adi Nugroho

\section{PENDAHULUAN}

Manusia adalah makhluk Tuhan yang paling sempurna, kesempurnaan tersebut ditandai dengan mempunyai akal dan budi dalam Salim \& Salim (1991). Selain akal dan budi, manusia juga di bekali nafsu. Dalam paradigma psikoanalisis, nafsu ini berorientasi pada kenikmatan dalam Freud (2006). Dalam perjalananya, nafsu yang berorientasi kenikmatan ini menuntut untuk di penuhi. Berasal dari titik ini, manusia memiliki kebutuhan, seperti kebutuhan biologis dan seksual. Berbekal akal, manusia dapat mencari segala cara untuk memenuhi kebutuhannya, baik cara yang positif maupun cara yang negatif. Tingkah laku kriminalitas dapat dilakukan oleh siapa saja, kapan saja dan dimana saja, baik pria ataupun wanita, dapat berlangsung pada usia anak-anak, remaja, dewasa bahkan lanjut usia (Kartono, 2014)

Tujuan Lembaga Pemasyarakatan Kelas I Kutoarjo meliputi membentuk Warga Binaan Pemasyarakatan (anak didik) agar menjadi manusia seutuhnya, menyadari kesalahan, memperbaiki diri dan tidak mengulangi tindak pidana sehingga dapat diterima kembali oleh lingkungan masyarakat, dapat berperan aktif dalam pembangunan dan dapat hidup secara wajar sebagai warga yang baik dan bertanggung jawab. Selain itu, Memberikan jaminan perlindungan Hak Asasi Tahanan, narapidana dan warga binaan pemasyarakatan atau anak didik dalam rangka memperlancar proses pembinaan dan pembimbingan. Program Pembinaan dan pembimbingan yang diberikan kepada anak didik dilakukan oleh petugas-petugas lembaga pembinaan. Salah satu petugas lembaga pembinaan yaitu wali.

Wali merupakan merupakan petugas lembaga pembinaan yang diberikan tugas tambahan sebagai orang tua pengganti selama anak didik dibina didalam lembaga binaan, selain itu juga mendampingi segala kegiatan yang dilakukan oleh anak didik serta membantu anak didik ketika mengalami masalah. Setiap wali ditugaskan untuk mendampingi sekitar 8 sampai 10 orang anak didik dimana tugas seorang wali adalah membantu anak didik dalam mengatasi segala permasalahan yang dialami oleh anak didik di lembaga pembinaan khusus anak hampir keseluruhan petugas khususnya wali yang bekerja di lembaga pembinaan khusus anak ini tidak memiliki latar belakang pendidikan psikologi. Wali juga menjaga jarak dengan anak didik sehingga kedekatan mereka cenderung kurang karena untuk menjaga kewibawaan wali itu sendiri dan supaya anak didik tunduk terhadap perintah dan peraturan yang ada serta menjadikan anak didik tidak menyepelekan wali dan petugas lain di lembaga pembinaan yang ada.

Di Indonesia terdapat 17 (tujuh belas) Lembaga Pembinaan khusus anak. Khususnya untuk wilayah Provinsi Jawa Tengah dan Daerah Istimewa Yogyakarta terdapat satu Lembaga Pemasyarakatan Anak yakni di Lembaga Pembinaan Khusus Anak kelas I Kutoarjo (Kabupaten Purworejo). Lokasi Lembaga Pemasyarakatan ini pun strategis dan keadaan lingkungannya dinilai cukup baik dengan fasilitas yang ada. Pembinaan yang dilakukan terhadap anak didik lembaga pembinaan sebagian besar sudah sesuai dengan peraturan hukum yang berlaku di Negara Indonesia, akan tetapi bekal kemampuan untuk melakukan pembinaan cenderung kurang dan hubungan antara wali denga anak didik cenderung kurang dekat dan dalam lapas kutoarjo para narapidana kurang memiliki kesejahteraan di karenakan di dalam lapas tidak adanya yang berjualan makanan ringan ataupun minuman. Jadi napi anak cenderung makan dan minum seadanya dan sama terus menu makanannya, sehingga anak merasa tidak sejahtera

Dan Narapidana Anak menurut undangundang Nomor 12 Tahun 1995 tentang 
38 Hubungan antara dukungan sosial keluarga dengan psychological well-being paa narapidana anak di Lapas Klas 1 Kutoarjo - Yehezkiel Adi Nugroho

permasyarakatan adalah narapidana, anak didik permasyarakatan dan klien permasyarakatan, Selanjutnya pasal 1-8 Undang-undang Nomor 12 tahun 1995 tentang permasyarakatan menyebutkan bahwa: (1) Narapidana anak adalah berdasarkan putusan pengadilan yang menjalani pidana di LAPAS anak paling lama sampai berumur 18 (delapan belas) tahun. (2) Anak negara adalah berdasarkan putusan pengadilan diserahkan pada negara untuk dididik dan ditempatkan di LAPAS anak paling lama sampai berumur 18 (delapan belas tahun). (3) Anak sipil adalah anak yang atas permintaan orang tua atau walinya memperoleh penetapan pengadilan untuk dididik di LAPAS anak paling lama sampai berumur 18 tahun.

Dalam pasal 1 ke 8 undang-undang Nomor 12 tahun 1995 tentang permasyarakatan menyebutkan bahwa suatu kegiatan untuk melakukan pembinaan kepada warga binaan permayarakatan berdasarkan sistem, kelembagaan dan cara pembinaan yang merupakan bagian akhir dari sistem pembinaan dalam peradilan pidana. Sedangkan dalam pasal 1 ke 3 undang-undang nomor 12 tahun 1995 tentang permasyarakatan disebutkan bahwa lembaga permayarakatan yang selanjutnya disebut lapas adalah pranata untuk melaksanakan pembinaan narapidana dan anak didik pemasyarakatan. Kasus yang ada pada Lapas Khusus Anak Kutoarjo terdiri dari berbagai kasus antara lain, pencurian, tindak asusila, penganiayaan, narkoba dan minuman keras.

Melihat masalah-masalah yang potensial, seperti yang sudah dipaparkan di atas, maka perlu diperoleh suatu cara untuk mencegah atau mengurangi beban dari masalah tersebut, untuk mempertahankan harapan hidup pada narapidana anak, salah satu cara yang dapat dilakukan oleh narapidana anak adalah dengan mencapai Psychological Well-Being yang optimal. Psychological Well-Being adalah suatu kondisi psikologis individu sehat, yang ditandai dengan berfungsinya aspek-aspek psikologis positif dalam proses mencapai aktualisasi diri.

Psychological Well-Being penting untuk dilakukan karena nilai positif dari kesehatan mental yang ada di dalamnya membuat seseorang dapat mengidentifikasi apa yang hilang dalam hidupnya (Ryff, dalam Compton, 2005). Psychological Well-Being menurut Ryff (1989) adalah sebuah istilah yang dapat digunakan untuk menggambarkan kesehatan psikologis individu sesuai dengan pemenuhan kriteria fungsi psikologi positif. Ryff (1989) juga menyatakan aspek dari Psychological Well-Being, yaitu penerimaan diri (self acceptance), hubungan positif dengan orang lain (positive relationship with other), otonomi (autonomy), penguasaan lingkungan (environmental mastery), tujuan hidup (purpose in life), dan pertumbuhan pribadi (personal growth).

Dari informasi tersebut dapat di jelaskan lebih lanjut yaitu: pertama, penerimaan diri merupakan aktualisasi diri yang baik, menuju pada kematangan individu dan pemfungsian diri yang optimal. Kedua, hubungan positif dengan orang lain artinya kemampuan untuk membangun hubungan yang dekat dan hangat dengan orang lain. Selain itu adanya kontak dan hubungan sosial yang memuaskan (Keyes \& Waterman, 2003). Dampak PWB terhadap narapidana anak menunjukan pentingnya Psychological Well-Being yang tinggi untuk dimiliki narapidana anak.

Tanpa Psychological Well-Being yang tingi untuk dimiliki narapidana anak akan cenderung memiliki kesehatan fisik yang buruk, tidak produktif, dan pada akhirnya akan menjadi beban pada keluarga mereka. Karena itu merupakan hal yang sangat penting untuk mengetahui faktor yang memengaruhi pembentukan Psychological Well-Being narapidana anak. Berbagai penelitian mengenai Psychological Well-Being telah banyak dilakukan dan dapat di ketahui bahwa terdapat perbedaan 
39 Hubungan antara dukungan sosial keluarga dengan psychological well-being paa narapidana anak di Lapas Klas 1 Kutoarjo - Yehezkiel Adi Nugroho

faktor-faktor yang mempengaruhi Psychological Well-Being seseorang.

Adapun faktor-faktor yang mempengaruhi Psychological Well-Being menurut (Ryff \& Keyes 1995), antara lain: usia, jenis kelamin, status sosial ekonomi, dukungan sosial, religiusitas, dan kepribadian. Salah satu faktor yang mendukung Psychological Well-Being adalah dukungan sosial (Ryff \& Keyes 1995). Weiss (dalam Cutrona, 1994) mendefinisikan bahwa dukungan sosial adalah pertukaran interpersonal dimana salah seorang memberikan bantuan atau pertolongan kepada orang lain. Keberadaan keluarga dan jaringan sosial yang memberikan dukungan sosial menunjukan kontribusi terhadap peningkatan Psychological Well-Being (Litwin,2006). Dukungan ini dapat berasal dari berbagai sumber diantaranya orang yang dicintai seperti orang tua, pasangan, anak, teman, dan kontak sosial dengan masyarakat (Rietschlin, dalam Taylor, 2009).

$$
\text { Weiss (dalam Cutrona, 1994) }
$$

mengemukakan adanya enam komponen dukungan sosial yang disebut sebagai "The Social Provision Scale" dimana masing-masing komponen dapat berdiri sendiri, namun satu sama lain saling berhubungan. Adapun komponen tersebut yaitu Reliable Alliance (ketergantungan yang dapat diandalkan), Guidance (Bimbingan), Reassurance of Worth (Pengakuan Positif), Emotional Attachment (Kedekatan emosional), Social Integration (Integrasi sosial), Opportunity to Provide Nurturance (Kesempatan untuk mengasuh)

\section{Hubungan dukungan sosial keluarga} dengan Psychological Well-Being pada narapidana anak di Lapas Kutoarjo, adalah saat keluarga membesuk narapidana anak pada jadwal yang sudah diberikan oleh pihak lapas yaitu hari jumat dari jam 10.00-12.00 WIB. Pada saat besuk tersebut narapidana anak mendapatkan dukungan dari keluarga yang diantaranya mendapatkan nasehat dari keluarga, penguatan positif dari keluarga agar narapidana anak dapat menjalani masa pidana/pembinaan dengan baik. Selain itu narapidana anak juga mendapatkan baju baru dari keluarga, makanan ringan yang dari pihak lapas tidak tersedia dll. Ketika narapidana anak mendapat dukungan sosial tinggi maka akan mempengaruhi Psycohological-Well-Being, sebagaian besar penelitian terdahulu dalam penelitian yang dilakukan oleh Millatina dan Yanuvianti Tahun (2014) meneliti hubungan antara dukungan sosial dengan Psychological Well-Being menunjukan hasil hubungan positif terhadap dukungan sosial dengan Psychological Well-Being. Namun penelitian yang dilakukan oleh Sari dan Suprapti (2013) tentang pengaruh dukungan sosial keluarga terhadap Psychological Well-Being pada masa pensiun menujukan hasil yang berbeda yakni tidak terdapat pengaruh antara dukungan keluarga dengan psychological WellBeing pada masa pensiun. Berdasarkan fenomena diatas dan pro-kontra penelitian tersebut, membuat peneliti merasa tertarik untuk melakukan penelitian mengenai "Hubungan antara Dukungan Sosial Keluarga dengan Psychological Well-Being pada Narapidana Anak di Lapas Kutoarjo". Hipotesis dalam penelitian ini adalah "Ada hubungan positif antara dukungan sosial keluarga dan Psychological Well-Being pada Narapidana Anak di Lapas Kutoarjo". Semakin tinggi tingkat dukungan sosialnya maka akan semakin tinggi Psychological Well-Being dan semakin rendah tingkat dukungan sosialnya maka akan semakin rendah juga tingkat Psychological Well-Being.

\section{METODE}

Penelitian ini menggunakan metode kuantitatif jenis korelasional. Penelitian korelasional menurut Fraenkel dan Wallen (2008) adalah suatu penelitian yang digunakan untuk mengetahui hubungan dan tingkatan hubungan antara dua 
40 Hubungan antara dukungan sosial keluarga dengan psychological well-being paa narapidana anak di Lapas Klas 1 Kutoarjo - Yehezkiel Adi Nugroho

variabel atau lebih tanpa ada upaya untuk mempengaruhi variabel tersebut sehingga tidak terdapat manipulasi variabel. Adapun penerapan penelitian korelasional pada penelitian ini digunakan untuk mengetahui hubungan dukungan sosial dengan Psychological Well-Being pada narapidana anak.

\section{HASIL DAN PEMBAHASAN}

Kategori dibagi menjadi 4 yaitu sangat tinggi, tinggi, rendah dan sangat rendah. Pembagian interval dilakukan dengan mengurangi jumlah skor tertinggi dengan skor terendah dan membaginya dengan jumlah kategori.

\section{$i=\frac{\text { skor tertinggi }- \text { skor terendah }}{\text { ten }}$}

jumlah kategori

Dari perhitungan memakai rumus tersebut, maka didapatkan hasil seperti pada table di bawah ini:

Table 1 Table Dukungan Sosial Keluarga

\begin{tabular}{|c|c|c|c|c|c|}
\hline $\begin{array}{l}\text { Katego } \\
\text { ri }\end{array}$ & $\begin{array}{l}\text { Interv } \\
\text { al }\end{array}$ & $\begin{array}{l}\text { Frekuen } \\
\text { si }\end{array}$ & $\begin{array}{l}\text { Persenta } \\
\text { se }\end{array}$ & $\begin{array}{l}\text { Mea } \\
\mathrm{n}\end{array}$ & SD \\
\hline $\begin{array}{l}\text { Sangat } \\
\text { tinggi }\end{array}$ & $\begin{array}{l}78 \leq x \\
<96\end{array}$ & 24 & $45 \%$ & & \\
\hline Tinggi & $\begin{array}{l}60 \leq x \\
<78\end{array}$ & 25 & $47 \%$ & $\begin{array}{l}73.8 \\
7\end{array}$ & $\begin{array}{l}10.3 \\
3\end{array}$ \\
\hline Rendah & $\begin{array}{l}42 \leq x \\
<60\end{array}$ & 4 & $8 \%$ & & \\
\hline $\begin{array}{l}\text { Sangat } \\
\text { rendah }\end{array}$ & $\begin{array}{l}24 \leq x \\
<42\end{array}$ & 0 & $0 \%$ & & \\
\hline
\end{tabular}

N $\quad 53$

Dari data di atas dapat di tarik kesimpulan bahwa tingkat dukungan sosial keluarga terhadap narapidana anak dari 53 partisipan menunjukan kategori yang bervariasi, dimulai dari kategori sangat tinggi dengan prenstasi $45 \%$, kategori tinggi $47 \%$, kategori rendah $8 \%$, sedangkan pada kategori sangat rendah $0 \%$, mean yang di peroleh adalah 73,87 dengan standar deviasi sebesar 10,33. Berdasarkan mean dan standar deviasi yang di peroleh, maka dukungan sosial yang dimiliki narapidana anak berada pada kategori tinggi.
Table 2 Table Psychological well-being

\begin{tabular}{llllll}
\hline Kategori & Interval & Frekuensi & Persentase & Mean & SD \\
\hline $\begin{array}{l}\text { Sangat } \\
\text { tinggi }\end{array}$ & $\begin{array}{l}81,25 \leq \mathrm{x} \\
<100\end{array}$ & 16 & $30 \%$ & & \\
Tinggi & $\begin{array}{l}62,5 \leq \mathrm{x} \\
<81,25\end{array}$ & 31 & $58 \%$ & 74.70 & 9.44 \\
Rendah & $\begin{array}{l}43,75 \leq \mathrm{x} \\
<62,5\end{array}$ & 6 & $11 \%$ & & \\
Sangat & $\begin{array}{l}25 \leq \mathrm{x} \\
\text { rendah }\end{array}$ & 0 & $0 \%$ & \\
\hline & & 53,75 & 0 & &
\end{tabular}

Dari data di atas dapat di tarik kesimpulan bahwa tingkat psychological well-being terhadap narapidana anak di lapas kutoarjo dari 53 partisipan menunjukan kategori yang bervariasi, dimulai dari kategori sangat tinggi dengan presentase $30 \%$, kategori tinggi $58 \%$, kategori rendah $11 \%$, sedangkan pada kategori sanga trendah $0 \%$. Mean yang di peroleh adalah 74,70 dengan standar deviasi sebesar 9,44. Berdasarkan mean dan standar deviasi yang di peroleh, maka psychological well-being yang dimiliki oleh narapidana anak dilapas kutoarjo berada pada kategori sangat tinggi.

Pada tabel di bawah terdapat hasil uji normalitas dengan Kolmogorov- Smirnov Test. Pada variabel dukungan sosial keluarga memiliki nilai signifikansi sebesar 0,731 ( $>0,05)$. Sedangkan hasil dari variabel Psychological wellbeing memiliki nilai signifikasi sebesar 0,964 $(\mathrm{p}>0,05)$.

\begin{tabular}{|c|c|c|c|}
\hline & & DKS & PWB \\
\hline $\mathrm{N}$ & & 53 & 53 \\
\hline \multirow{2}{*}{$\begin{array}{l}\text { Normal } \\
\text { Parameters }\end{array}$} & Mean & 73.8679 & 74.6981 \\
\hline & Std. Deviation & 10.32554 & 9.43517 \\
\hline \multirow{3}{*}{$\begin{array}{l}\text { Most Extreme } \\
\text { Differences }\end{array}$} & Absolute & .095 & .069 \\
\hline & Positive & .095 & .046 \\
\hline & Negative & -.089 & -.069 \\
\hline \multicolumn{2}{|c|}{ Kolmogorov-Smirnov Z } & 688 & .500 \\
\hline \multicolumn{2}{|c|}{ Asymp. Sig. (2-tailed) } & .731 & .964 \\
\hline
\end{tabular}

a. Test distribution is Normal.

Pengujian Linearitas pada variable dukungan sosial keluarga dan variable Psychological Well-Being. Pada hasil tersebut menunjukan nilai 0,669 dengan nilai signifikan 0,846(p >0,05) hasil ini dapat dikatakan bahwa hubungan antara dukungan sosial dengan 
41 Hubungan antara dukungan sosial keluarga dengan psychological well-being paa narapidana anak di Lapas Klas 1 Kutoarjo - Yehezkiel Adi Nugroho

Psychological Well-Being dikatakan sejajar atau linear.

\begin{tabular}{|c|c|c|c|c|c|c|}
\hline \multirow{4}{*}{$\begin{array}{l}* \text { Between } \\
\text { Groups }\end{array}$} & & $\begin{array}{l}\text { Sum o } \\
\text { Squares }\end{array}$ & $\mathrm{df}$ & $\begin{array}{l}\text { Mean } \\
\text { Square }\end{array}$ & $\mathrm{F}$ & Sig. \\
\hline & $\begin{array}{l}\text { (Combine } \\
\text { d) }\end{array}$ & $\begin{array}{l}3332.75 \\
3\end{array}$ & 30 & 111.092 & 1.885 & .064 \\
\hline & Linearity & $\begin{array}{l}2189.26 \\
8\end{array}$ & 1 & 2189.268 & $\begin{array}{l}37.15 \\
2\end{array}$ & .000 \\
\hline & $\begin{array}{l}\text { Deviation } \\
\text { from } \\
\text { Linearity }\end{array}$ & $\begin{array}{l}1143.48 \\
5\end{array}$ & 29 & 39.431 & .669 & .846 \\
\hline \multicolumn{2}{|c|}{ Within Groups } & $\begin{array}{l}1296.41 \\
7\end{array}$ & 22 & 58.928 & & \\
\hline \multicolumn{2}{|l|}{ Total } & $\begin{array}{l}4629.17 \\
0\end{array}$ & \multicolumn{2}{|l|}{52} & & \\
\hline
\end{tabular}

Hubungan antara kedua variable tersebut dihitung menggunakan uji korelasi product moment-pearson. Hasil yang di dapat adalah nilai koefisien korelasi sebesar $\mathrm{r}=0,688$ dengan signifikansi sebesar $0,000(\mathrm{p}<0,05)$ bahwa terdapat hubungan positif antara Dukungan Sosial keluarga dengan Psychological Well-Being pada Narapidana Anak di Lapas Kutoarjo. Hasil pengujian hipotesis tersebut dapat di lihat pada tabel di bawah ini:

\begin{tabular}{lll} 
& \multicolumn{2}{l}{ Table 5 Correlations } \\
\hline & $\mathrm{X}$ & $\mathrm{Y}$ \\
\hline Pearson Correlation & 1 & $.688^{* *}$ \\
Sig. (1-tailed) & & .000 \\
$\mathrm{~N}$ & 53 & 53 \\
\hline Pearson Correlation & $.688^{* *}$ & 1 \\
Sig. (1-tailed) & .000 & \\
$\mathrm{~N}$ & 53 & 53 \\
**. Correlation is significant at the 0.01 level (1-tailed).
\end{tabular}

Berdasarkan hasil dari penelitian mengenai dukungan sosial keluarga dengan Psychological Well-Being ini di peroleh hasil nilai koefisien korelasi sebesar $r=0,688$ dengan signifikansi sebesar $0,000(p>0,05)$ yang berarti ada hubungan positif antara dukungan sosial keluarga dengan Psychological Well-Being pada Narapidana Anak di Lapas Kutoarjo, sehingga hipotesis yang di ajukan dalam penelitian ini dapat di terima. Narapidana anak memiliki dukungan sosial keluarga paling banyak dalam kategori tinggi sebanyak 47\%, sedangkan Psychological
Well-Being pada narapidana anak pada kategori tinggi sebanyak 58\%. Hal ini di dukung dengan penelitian yang di lakukan oleh Millatina dan Yanuvianti Tahun (2014) terlihat jelas bagaimana kualitas dukungan sosial mempengaruhi tingkat Psychological Well-Being.

$$
\text { Amawidyati dan Utami (2007) }
$$
mengungkapkan bahwa sikap positif seperti ketabahan, adanya penerimaan, serta hubungan yang positif dengan orang lain yang menyebabkan terbentuknya kondisi psikologis yang positif, hal ini dapat di tinjau pada fenomena di lapangan, narapidana anak merasa lebih banyak belajar dari masa lalunya, karena akibat kesalahan masa lalu membuat ia mengerti apa yang harus dibenahi di masa depan, di dalam penjara narapidana juga merasa senang karena mengenal orang-orang baru, dan mempunyai hubungan yang baik di dalam panti, di sini narapidana mempunyai wadah untuk bercerita tentang masalah pribadi sehingga ada penguatan positif dari orang sekitar yang membuat para narapidana menjadi tabah dalam menjalani ujian hidup.

Dukungan sosial merupakan keberadaan orang lain yang dapat di andalkan untuk memberi bantuan, semangat, penerimaan,dan perhatian, sehingga bisa meningkatkan kesejahteraan atau kualitas hidup bagi individu yang bersangkutan (Jhonson \& Jhonson, 1991). Teori ini memperkuat fenomena yang terdapat dilapangan yang menunjukan adanya peningkatan Psychological Well-Being dari para narapidana anak kehadiran keluarga yang membesuk napi di sini para napi sangat senang sekali ketika kehadiran seseorang yang membesuknya, karena ketika napi di besuk keluarga, mereka memberikan sesuatu, misalnya: uang saku, perlengkapan mandi, makanan.

Menurut Rathi dan Rastogi (2007), stress merupakan salah satu faktor yang dapat mempengaruhi tingkat tinggi rendahnya Psychological Well-Being pada diri seseorang. 
42 Hubungan antara dukungan sosial keluarga dengan psychological well-being paa narapidana anak di Lapas Klas 1 Kutoarjo - Yehezkiel Adi Nugroho

Teori ini juga sependapat dengan Penelitian yang di lakukan oleh Yasin dan Dzulkifli (2010), menyatakan bahwa kurangnya dukungan sosial menjadi salah satu factor yang menyebabkan masalah psikologis. Setiap dimensi dalam dukungan sosial memiliki peran masing-masing yang dapat mempengaruhi psychological wellbeing pada narapidana anak di lapas kutoarjo, dukungan sosial memberikan sumbangan efektif terhadap psychological well-being sebesar $47,33 \%$ yang artinya masih terdapat faktor-faktor lain yang dapat mempengaruhi seperti usia,jenis kelamin, sosio ekonomi, religiusitas, dan kepribadian.

\section{SIMPULAN}

Berdasarkan hasil penelitian yang sudah di3uraikan, maka dapat di tarik beberapa kesimpulan: Terdapat hubungan positif yang signifikan antara variabel dukungan sosial dengan Psychological Well-Being pada narapidana anak di Lapas Kutoarjo. Semakin tinggi mendapatkan dukungan sosial keluarga kepada narapidana anak maka semakin tinggi juga Psychological WellBeing, begitu juga sebaliknya narapidana anak yang kurang mendapatkan dukungan sosial keluarga maka semakin rendah Psychological Well-Being yang dimilikinya. Narapidana anak memiliki dukungan sosial keluarga paling banyak dalam kategori tinggi sebanyak 57\%, sedangkan Psychological Well-Being pada narapidana anak berada pada kategori tinggi sebanyak, $51 \%$.

\section{DAFTAR PUSTAKA}

Amawidyati, S. A. G.\& Utami, M. S. (2007). Religiusitas dan psychological well being pada korban gempa. Jurnal Psikologi Universitas Gajah Mada, 34, 164-176. DOI: 10.22146/jpsi.7095

Azwar, S. 2004. Validitas dan reliabilitas. Yogyakarta: Pustaka Pelajar.

Cutrona, C. E, et. Al. (1994). Peceived parental social support and academic achievement : an attachment theory perspective. Journal of Personality and Social Psychology. 66(2), 369-378

Johnson, D. W. \& Jhonson, F.P. (1991). Joining Together: Group Theory and Group Skills. Fourth Edition. London: Prentice Hall International

Kartono, K. (2014). Patologi sosial. Jakarta: Rajawali.

Keyes, C. L. M., \& Waterman, M. B. (2003). Dimensions of Well-Being and Mental Health In Adulthood-En M. Bornstein, L. Davidson, CLM Keyes y K. Moore (eds.), Well-being: Positive Development Throughout the Life Course (pp. 447-497).

Lubis, S.M., \& Maslihah, S. (2012). Analisis sumber-sumber kebermaknaan hidup narapidana yang menjalani hukuman seumur hidup. Jurnal Psikologi Universitas Diponegoro,11(1), 28-39.

Millatina, A. dan Yanuvianti, M. 2015. Hubungan antara Dukungan Sosial dengan Psyhological Well-Being pada Wanita Menaupose (di RS Harapan Bunda Bandung).

http://karyailmiah.unisba.ac.id/index.php/p sikologi/article/view/1250

Ryff, C. D. (1989). Happines is everything, or is it? Explorations on the meaning of Psychological Well-Being. Journal of personality and Social Psychology, 57, 1069-1081. DOI: $10.1037 / 0022$ 3514.57.6.1069

Ryff, C. D., \& Keyes, C. L. (1995). The structure of psychological well-being revisited. Journal of Personality and Social Psychology, 69, 719-727. DOI: 10.1037/0022-3514.09.4.719

Ryff, C. D., \& Singer, B. H. (2006). Best news yet on the six-factor model of wellbeing. Social Science Research, 35(4), 1103-1119.

Sari, D., \& Suprapti, V. (2013). Pengaruh dukungan sosial keluarga terhadap Psychological well-being pada masa pensiun. Jurnal Psikologi Pendidikan Dan Perkembangan 2

Sarafino,E.P. (1998). Health Psychology : Biopsychososial Interactions. Third

Edition. United States of American : John Wiley \& Sons. Inc

Soetjiningsih, Christiana Hari. (2012). Perkembangan Anak sejak Pembuahan 
43 Hubungan antara dukungan sosial keluarga dengan psychological well-being paa narapidana anak di Lapas Klas 1 Kutoarjo - Yehezkiel Adi Nugroho

sampai denganAnak-anak Akhir. Jakarta:

Prenada Media Group

Yasin, Safree, A., \& Dzulkifli, M. A., (2010). The

relationship between social support and

psychological problems among students 